\title{
Molecular characterization of glutathione S-transferase, endothelial nitric oxide synthase and Vitamin $D$ receptor genes in breast cancer cases \\ Rizk El-Baz ${ }^{(1)}$; Azza Ismail ${ }^{(2)}$; Maher Amer ${ }^{(2)}$; Mai Elshahat ${ }^{(3)}$; Amira \\ Kazamel $^{(2)}$; Ahmad Settin ${ }^{(1)}$ \\ (1)Genetics Unit, Children Hospital, Mansoura University, Egypt \\ (2) Physiology Department, Faculty of Science, Mansoura University, Egypt \\ (3) Clinical Oncology \& Radiology, Mansoura University, Egypt
}

\begin{abstract}
Background: Enzymes of the Glutathione S-transferase system (GST) modulate the effects of exposure to several cytotoxic and genotoxic agents. Nitric oxide (NO) is constitutively synthesized in the endothelium by endothelial nitric oxide synthase (eNOS) and acts as a pleiotropic regulator involved in carcinogenesis. Vitamin D levels may influence breast cancer development. The vitamin D receptor (VDR) is a crucial mediator for the cellular effects of vitamin D and additionally interacts with other cell-signaling pathways that influence cancer development.
\end{abstract}

Objectives: To check for the association of polymorphisms of GST, eNOS3 and VDR genes with the susceptibility and severity of breast cancer in Egyptian cases.

Subjects: This work included 100 cases with breast cancer and 100 healthy individuals. The mean age of cases was $48.31 \pm 11.40$ years. They included 100 females.

Methods: DNA was amplified using PCR-RFLP for detection of polymorphisms related to eNOS3 and VDR, also DNA was amplified using PCR-SSP for detection of polymorphisms related to GST and calculating the odds ratios and their $95 \%$ confidence intervals.

Results: Total cases showed high significant frequency of $\mathrm{eNOS}^{-786} \mathrm{CC}(\mathrm{P}<0.05, \mathrm{OR}=18.58)$ genotypes, GSTT1(null) (OR = 2.68; CI 95\%=1.51-4.75; $\mathrm{p}=0.001)$. These were considered risk genotypes for disease susceptibility. On the other hand, total cases showed low significant frequency with homozygosity for eNOS3 ${ }^{-786} \mathrm{TT}(\mathrm{P}=0.01)$ and the GSTT1 gene was present in $42.0 \%$ of the cancers and in $66.0 \%$ of controls $(\mathrm{OR}=0.37$; CI $95 \%=0.21-0.66 ; \mathrm{p}=0.001)$. These may be considered low risk genotypes. No significant difference in frequencies of null and present genotypes of GSTM1 and VDR FOKI in total cases compared to controls.

Conclusions: Polymorphisms related to eNOS3 ${ }^{-786}$, GSTT1 and VDR FOKI genes may be considered genetic markers for BC among Egyptian cases. This may have potential impact on family counselling as well as future management plans.

Keywords: BC: Breast Cancer, eNOS: Endothelial nitric oxide synthase, PCR-RFLP: polymerase chain reaction with Restriction fragment length polymorphism, PCR-SSP: polymerase chain reaction with sequence specific primers. SNP: single nucleotide 
polymorphism, GSTT: Glutathione S-transferase Theta, GSTM: Glutathione S-transferase Mu, VDR :Vitamin d receptor.

\section{Introduction}

Breast cancer is the most common malignancy in women in the Western world, with an incidence approaching one in 10 in the US in 1980 (King et al.,1993) and one in 11 in Australia in 1991 (Curran et al., 2000). In Egypt, breast cancer is the most common cancer among women, representing $18.9 \%$ of total cancer cases (35.1\% in women and $2.2 \%$ in men) among the Egypt National Cancer Institute (NCI) series of 10556 patients during the year 2001, with an age-adjusted rate of 49.6 per 100000 population (Lehman et al.,2008). Several genetic and environmental risk factors for the development of breast cancer are already known, including mutations within the BRCA1 and BRCA2 genes (Zheng et al.,2000).

The glutathione S-transferase supergene family consists of four gene subfamilies (GSTA, GSTM, GSTT and GSTP) which play a central role in the inactivation of toxic and carcinogenic electrophiles (Hayes and Pulford, 1995). Certain genes within the GSTM1 and GSTT1 subfamilies exhibit deletion polymorphisms (Seidegård et al., 1986) which have been associated with cancer susceptibility (Chenevix-Trench et al., 1995).

NO can be synthesized from Larginine by nitric oxide synthase (NOS).
Various isoforms of NOS exist, depending on the site of origin: endothelial (eNOS), neuronal (nNOS), and inducible (iNOS). In endothelial or epithelial cells, including those of the breast, eNOS is constitutively expressed and can produce a modest amount of NO that plays an important role in these cells' functions; therefore, NO may play a role in the etiology of breast cancers(Stuehr,1999).

Vitamin -D is a member of the steroid receptor family and mediates the effects of the active metabolite $1,25(\mathrm{OH})_{2}$ Vit $\mathrm{D}_{3}$ by regulating transcription of a number of different cellular genes. The action of vitamin $\mathrm{D}$ is mediated through binding to its nuclear receptor (VDR). In response to hormone binding, the VDR regulates the transcriptional activity of $1,25(\mathrm{OH})_{2} \mathrm{D}_{3}$ responsive genes by complexing with a vitamin D response element located in the promoter region of target genes. The vitamin D receptor (VDR) gene Fok I polymorphism represents a strong positional candidate susceptibility gene for different diseases like Prostate cancer, Urolithiasis, Inflammatory bowl disease and Osteoporosis (Gross et al., 1996).

This work was planned in order to test the association of polymorphisms of eNOS3 ${ }^{-786}$, GSTT1, GSTM1 and VDR FOKI with breast cancer in Egyptian cases. 


\section{Subjects and Methods}

This study included 100 cases with breast cancer recruited from the Oncology and Radiotherapy Department, Mansoura University, which is the main referral site in the Nile Delta Region of Egypt. They comprised $100(100 \%)$ females with a mean $\pm \mathrm{SD}$ of $48.31 \pm 11.40$ years. Of these cases, According to consanguinity, cases were classified into $85(85.0 \%)$ positive and 15(15.0\%) negative cases. According to family history, cases were classified into $82(82.0 \%)$ positive and $18(18.0 \%)$ negative cases. According to Socioeconomic standard, cases were classified into $39(39.0 \%)$ low, 58(58.0\%) moderate and $3(3.0 \%)$ high. According to education, cases were classified into 91(91.0\%) low, 4(4.0\%) median and 5(5.0\%) high. According to nutrition, cases were classified into 3(3.0\%) good, 62(62.0\%) moderate and 35(35.0\%) high. According to pollution, cases were classified into $20(20.0 \%)$ positive and $80(80.0 \%)$ negative cases. Regarding to data of breast cancer cases related to obstetric and gynecologic history, this study included $82(82.0 \%)$ positive cases with abortion and $18(18.0 \%)$ negative cases. According to menopause, cases were classified into 68(68.0\%) premenopausal and 32(32.0\%) postmenopausal. According to Oral contraceptive, cases were classified into $64(64.0 \%)$ positive and $36(36.0 \%)$ negative cases. Regarding to data of breast cancer cases related to examination and investigations, this study included
21(21.0\%) positive cases with lymph node and $89(89.0 \%)$ negative cases. According to estrogen receptors, cases were classified into 54(54.0\%) positive and 46(46.0\%) negative cases. According to progesterone receptors, cases were classified into $54(54.0 \%)$ positive and $46(46.0 \%)$ negative cases. Case genotypes were compared to 100 healthy unrelated volunteers from the same locality. They included 100 females. Informed consent was taken from all subjects and an approval was obtained from University Scientific and Ethical Committees to carry out the research as well.

\section{DNA extraction and purification}

After obtaining informed consent from all cases and controls, venous blood samples $(3 \mathrm{ml})$ were collected on EDTA (ethylenediamine tetra acetate) containing tubes, DNA was extracted promptly using DNA extraction and purification kit (Gentra Systems, USA) according to manufacturer's instructions and then stored at $-20{ }^{0} \mathrm{C}$ till use.

\section{PCR amplification}

PCR solution with primers hybridizing to the 5' region of exon 4 (5'CTGCCCTACTTGATTGATGGG-3') and the $3^{\prime}$ region of exon 5 (58CTGGATtGTAGCAGATCATGC-3') of GSTM1 was used to amplify a 273-basepair (bp) fragment (Comstock et al., 1990). Control primers that amplify b-actin (493 bp) were also included in each reaction to confirm the presence of amplifiable DNA in the sample (5'- 
GGGCACGAAGGCTCATCATT-3') and (5' GGCCCCTCCATCGTCCACCG-3') (Wiencke et al., 1995). Similarly, a PCR solution with primers for the 3'-coding region of the human GSTT1 (5'TTCCTTACTGGTCCTCACATCTC and 5'-TCACCGGATCATGGCCAGCA) was used to amplify a 480-bp fragment (Cheng et al., 1995). PCR reaction was carried out in a total volume of $25 \mathrm{ul}$ containing $10 \mathrm{pmol}$ of each primer, 2.5 $\mathrm{mmol} / \mathrm{L}$ of $\mathrm{MgCl} 2, \quad 0.2 \mathrm{mmol} / \mathrm{L}$ of each deoxynucleotide triphosphate, 1 unit of Taq polymerase. And $100 \mathrm{ng}$ of genomic DNA. Amplification was performed by initial denaturation at $94^{\circ} \quad \mathrm{C}$ for 5 minutes, followed by 30 cycles at $94^{0} \mathrm{C}$ for 1 minute, $64^{\circ} \mathrm{C}$ for 1 minute and $72^{0} \mathrm{C}$ for 1 minute and a final extension of $72^{0} \mathrm{C}$ for 7 minutes. In both assays, the absence of the PCR product was indicative of the null genotype (homozygous deletion). These assays do not distinguish between heterozygous and homozygous wild-type genotypes. Laboratory personnel were blinded to case-control status, and $10 \%$ repeat samples were included in the PCR analysis to monitor quality control. All repeat samples for both the GSTM1 and GSTT1 genotypes were concordant.

The eNOS T-786C mutation was analyzed by polymerase chain reaction (PCR) using the following primers: 5'ATG CTC CCA GGG CAT CA-3' and 5'GTC CTT GAG TCT GAC ATT AGG G-3'. The reaction was performed in $50-\mu \mathrm{L}$ tubes containing $5 \mu \mathrm{L}$ of $10 \mathrm{xTaq}$ buffer, $2.5 \mu \mathrm{L}$ of a $10 \mu \mathrm{mol} / \mathrm{L}$ solution of each primer, $5.0 \mu \mathrm{L}$ of $2.0 \mathrm{mmol} / \mathrm{L} \mathrm{dNTP} \operatorname{mix}, 1.0 \mu \mathrm{L}$ of 50 $\mathrm{mmol} / \mathrm{L} \mathrm{MgCl}_{2}, 28.5 \mu \mathrm{L}$ of $\mathrm{dH}_{2} 0,5 \mathrm{U}$ of Taq polymerase, and $50 \mathrm{ng}$ of sample DNA. The reaction was run under the following conditions: $94^{\circ} \mathrm{C}$ for 7 minutes and then cycled 30 times at $94^{\circ} \mathrm{C}$ for 30 seconds, $57^{\circ} \mathrm{C}$ for 30 seconds, and $72^{\circ} \mathrm{C}$ for 30 seconds, followed by $72^{\circ} \mathrm{C}$ for 7 minutes; $7.5 \mu \mathrm{L}$ of the PCR product was digested with $10 \mathrm{U}$ of NgoM IV $0.5 \mu \mathrm{L}$ of $10 \mathrm{x}$ react 9 (GIBCO) and $1.5 \mu \mathrm{L}$ of $\mathrm{dH}_{2} \mathrm{O}$ (23). The $\mathrm{C}$ allele introduces a cut site for NgoM IV, allowing differentiation from the $\mathrm{T}$ genotype when the PCR products are separated on a $4 \%$ Nusieve agarose gel (Nakayama et al., 1999).

Reaction mixtures of $50 \mu 1$ were used in PCR for the VDR gene star $t$ codon polymorphism. The reaction mixture consisted of 100-200ng of genomic DNA, 2-6 pmol of forward and reverse primers, $1 \mathrm{x}$ Taq polymerase buffer( $1.5 \mathrm{mM}$ Mgcl2)(Genetix Biotech Asia Pvt. Ltd.), dNTPs200) $\mu \mathrm{M}$ each) and 1.5 units of Taq DNA polymerase(Bangalore genei India). The primers of the VDR gene :Forward(5'AGCTGGCCCTGGCACTGACTCTGCTC T3')Reverse(5'ATGGAAACACCTTGCTT CTTCTCCCTC-3').DNA samples were amplified in MJ Research PTC-100TM (Peltier Thermal Cycler) with cycling parametersas follows: Denaturation at $940 \mathrm{C}$ for $5 \mathrm{~min}, 35$ cycles at $940 \mathrm{C}$ for $30 \mathrm{~s}, 610 \mathrm{C}$ for $30 \mathrm{~s}$ and $720 \mathrm{C}$ for $1 \mathrm{~min}$ and one final cycle of extension at $720 \mathrm{C}$ for $7 \mathrm{~min}$. The $\mathrm{T} / \mathrm{C}$ polymorphism in the first of two-start 
codon (ATG) at the translation initiation site of the VDR gene was detected by RFLP using the restriction endonuclease Fok-I. The PCR product of the 265bp band was digested with 1.0 unit of Fok I restriction enzyme (New England Biolabs) and the reaction buffer and incubated at $370 \mathrm{C}$ for 4 hours; $10 \mu \mathrm{l}$ of the digested reaction .Digestion of the amplified $265 \mathrm{bp}$

The entire reaction volume plus 5 $\mu 1$ of bromophenol blue track dye were loaded into 2\% agarose gel (Boehringer Mannheim) containing ethidium bromide. Gels were electrophoresed for 20 minutes at $200 \mathrm{~V}$, photographed under UV light (320 $\mathrm{nm}$ ) and then scored for the presence or absence of specific band.

square test) and Odds ratio with a minimum level of significance of $<0.05$.

\section{Results}

Analysis of GSTT1 polymorphism (table 1, 2, 3, fig.1), showed that null genotype is significantly higher in total cases compared to controls $(\mathrm{OR}=2.68$, $\mathrm{P}<0.05)$. The same was observed for null genotype in total cases with high socioeconomic standard compared to controls $(\mathrm{OR}=67.0, \mathrm{P}=0.002)$. On the other hand, present genotype has shown significant lower frequency among total cases $(\mathrm{OR}=0.37, \mathrm{P}<0.05)$. The same was observed with present genotype with high socioeconomic standard compared to controls $(\mathrm{OR}=0.12, \mathrm{P}=0.002)$.

Analysis of GSTM1 polymorphism (table 1, 2, 3, fig.2), showed that there was no significant difference in frequencies of all
PCR product gave two fragments, of $169 \mathrm{bp}$ and 96 bp respectively if the product was excisable.8 Depending on the digestion pattern, individuals were scored as (ff) when homozygous for the presence of the Fok-I site, (FF) when homozygous for the absence of the Fok-I site, or (Ff) in case of heterozygosity (Bid et al., 2005)

\section{Detection of amplified products}

Statistical analysis: Data were processed and analyzed using the Statistical Package of Social Science (SPSS, version 10.0). The frequency of studied allelic polymorphisms among cases was compared to that of controls describing number and percent of each and tested for positive association using Fisher's exact test (modified Chi genotypes in total cases as well as between different studied subgroups.

Analysis of risk factors related to GST polymorphism (table 1, 2, 3, fig.2), showed that GSTT1 and GSTM1 genotype has no significant difference in frequencies of all genotypes in total cases as well as between different Studied subgroups. Interestingly, no significant difference was found in the frequencies of all studied gentypes. Analysis of eNOS3 ${ }^{-786}$ polymorphism (table 1, 2, 3, fig.3), showed that allele $\mathrm{C}$ is significantly higher in total cases compared to controls $(\mathrm{OR}=2.08, \mathrm{P}<0.05)$. The same was observed for CC genotype $(\mathrm{OR}=18.85$, $\mathrm{P}=0.0002)$. On the other hand, allele $\mathrm{T}$ has shown significant lower frequency among total cases $(\mathrm{OR}=0.48, \mathrm{P}=0.0008)$. The same was observed with TT genotype $(\mathrm{OR}=0.46$, $\mathrm{P}=0.01$ ). Regarding to moderate 
Molecular characterization of glutathione S-transferase....

socioeconomic standard, eNOS3 $3^{-786}$ polymorphism showed that $\mathrm{CC}$ genotype is significantly higher in total cases compared to controls $\quad(\mathrm{OR}=21.0, \quad \mathrm{P}<0.05)$. Interestingly, no significant difference was found in the frequencies of all studied alleles.Regarding to high socioeconomic standard, eNOS3 $3^{-786}$ polymorphism showed that allele $\mathrm{C}$ is significantly higher in total cases compared to controls $(\mathrm{OR}=9.28$, $\mathrm{P}<0.05)$. On the other hand, allele $\mathrm{T}$ has shown significant lower frequency among total cases $(\mathrm{OR}=0.1, \quad \mathrm{P}=0.02)$. No significant difference was found in the frequencies of all studied genotypes.

Analysis of VDR FOKI polymorphism (table 1, 2, 3, fig.4), it was noted that breast cancer cases had no significant difference in the frequencies of all genotypes and alleles in total cases compared to controls. Regarding the distribution of VDR FOKI genotypes, it is noted that moderate socioeconomic standard cases with breast cancer cases had a significantly lower frequency of the heterozygous Ff genotype of FOKI polymorphism compared to controls $(36.2 \%$ vs. $64.5 \%, \mathrm{p}=0.003)$, while they had no significant difference in the frequencies of FF, ff genotypes, $\mathrm{F}$ and $\mathrm{f}$ alleles in total cases compared to controls. Regarding the distribution of VDR FOKI genotypes, it is noted that high socioeconomic standard cases breast cancer cases showed significant higher frequency of $\mathrm{F} / \mathrm{F}$ homozygosity genotype among total cases compared to controls $(\mathrm{P}=0.009$, $\mathrm{OR}=0.03, \quad 95 \% \mathrm{CI}=0.001-0.6), \quad$ while showing significant lower frequency of F/f heterozygosity genotype compared to controls $(\mathrm{P}=0.009, \mathrm{OR}=32.8,95 \% \mathrm{CI}=1.5$ 716.5) . F and $f$ alleles frequency showed significant differences among total cases where $\mathrm{F}$ allele $(\mathrm{P}<0.05, \quad \mathrm{OR}=0.09$, 95\% $\mathrm{CI}=0.01-0.55)$ and $\mathrm{f}$ allele $(\mathrm{P}<0.05$, $\mathrm{OR}=11.0,95 \% \mathrm{CI}=1.8-66.93)$. 
Table (1): Comparison between all cases with breast cancer and healthy controls regarding their allele frequency and genotype distribution of T-786C eNOS3, FOKI VDR, GSTT1 and GSTM1 gene polymorphisms.

\begin{tabular}{|l|l|l|l|l|}
\hline & $\begin{array}{l}\text { Cases } \\
(\mathbf{n = 1 0 0})\end{array}$ & $\begin{array}{l}\text { Controls } \\
(\mathbf{n = 1 0 0})\end{array}$ & $\mathbf{P}$ & OR (95\% CI) \\
\hline T-786C n(\%) & & & & \\
\hline TT & $29(29.0)$ & $47(47.0)$ & $\mathbf{0 . 0 1 *}$ & $0.46(0.25-0.82)$ \\
\hline TC & $55(55.0)$ & $52(52.0)$ & 0.77 & $1.12(0.64-1.96)$ \\
\hline CC & $16(16.0)$ & $1(1.0)$ & $\mathbf{0 . 0 0 0 2} * *$ & $18.85(2.4-145.2)$ \\
\hline T & $113(56.5)$ & $146(73.0)$ & $\mathbf{0 . 0 0 0 8 * *}$ & $0.48(0.31-0.37)$ \\
\hline C & $87(43.5)$ & $54(27.0)$ & $\mathbf{0 . 0 0 0 8 * *}$ & $2.08(1.4-3.2)$ \\
\hline FOK1 n(\%) & & & & \\
\hline FF & $58(58.0)$ & $53(53.0)$ & 0.56 & $1.22(0.70-2.14)$ \\
\hline Ff & $37(37.0)$ & $46(46.0)$ & 0.25 & $0.86(0.39-1.21)$ \\
\hline ff & $5(5.0)$ & $1(1.0)$ & 0.21 & $5.21(0.59-45.45)$ \\
\hline F & $153(76.5)$ & $152(76.0)$ & 1.00 & $1.02(0.64-1.63)$ \\
\hline f & $47(23.5)$ & $48(24.0)$ & 1.00 & $0.97(0.61-1.54)$ \\
\hline GSTT1 n(\%) & & & & \\
\hline Present & $42(42.0)$ & $66(66.0)$ & $\mathbf{0 . 0 0 1 *}$ & $0.37(0.21-0.66)$ \\
\hline Null & $58(58.0)$ & $34(34.0)$ & $\mathbf{0 . 0 0 1 *}$ & $2.68(1.51-4.75)$ \\
\hline GSTM1 n(\%) & & & & \\
\hline Present & $53(53.0)$ & $55(55.0)$ & 0.88 & $0.92(0.52-1.60)$ \\
\hline Null & $47(47.0)$ & $45(45.0)$ & 0.88 & $1.08(0.62-1.89)$ \\
\hline
\end{tabular}

$\mathrm{n}=$ number of cases, $(\%)=$ percentage of cases, $\mathrm{OR}(95 \% \mathrm{CI})=$ Odds ratio $\& 95 \%$ confidence interval.Significance using Fisher's Exact test: $* \mathrm{p}=<0.05$ (significant), $* * \mathrm{p}=<0.001$ (extremely significant) 
Table (2 ): Comparison between all cases with moderate socioeconomic standard with breast cancer and healthy controls regarding their allele frequency and genotype distribution of T-786C eNOS3, FOKI VDR, GSTT1 and GSTM1 gene polymorphisms.

\begin{tabular}{|l|l|l|l|l|}
\hline & $\begin{array}{c}\text { cases } \\
(\mathbf{n = 5 8})\end{array}$ & $\begin{array}{l}\text { H. controls } \\
(\mathbf{n = 6 2})\end{array}$ & $\mathbf{P}$ & OR (95\% CI) \\
\hline T-786C n(\%) & & & & \\
\hline TT & $17(29.3)$ & $18(29.0)$ & 1.0 & $1.0(0.46-2.22)$ \\
\hline TC & $33(56.9)$ & $44(71.0)$ & 0.12 & $0.54(0.25-1.15)$ \\
\hline CC & $8(13.8)$ & $0(0.0)$ & $\mathbf{0 . 0 0 2} * *$ & $21.0(1.1-373.6)$ \\
\hline T & $67(57.8)$ & $80(64.5)$ & 0.29 & $0.75(0.44-1.26)$ \\
\hline C & $49(42.2)$ & $44(35.5)$ & 0.29 & $1.33(0.78-2.23)$ \\
\hline FOKI n(\%) & & & & \\
\hline FF & $35(60.3)$ & $22(35.5)$ & 1.0 & $2.76(1.3-5.79)$ \\
\hline Ff & $21(36.2)$ & $40(64.5)$ & $\mathbf{0 . 0 0 3} * *$ & $0.31(0.1-0.65)$ \\
\hline Ff & $2(3.4)$ & $0(0.0)$ & 0.23 & $5.53(0.25-117.7)$ \\
\hline F & $91(78.4)$ & $84(67.7)$ & 0.08 & $1.73(0.96-3.10)$ \\
\hline F & $25(21.6)$ & $40(32.3)$ & 0.08 & $0.54(0.32-1.03)$ \\
\hline GSTT1 n(\%) & & & & \\
\hline Null & $33(56.9)$ & $29(46.8)$ & 0.27 & $1.50(0.73-3.08)$ \\
\hline Present & $25(43.1)$ & $33(53.2)$ & 0.27 & $0.66(0.32-1.36)$ \\
\hline GSTM1 n(\%) & & & & \\
\hline Null & $25(43.1)$ & $36(56.9)$ & 0.14 & 0.14 \\
\hline Present & $36(58.1)$ & $26(41.9)$ & $1.82(0.88-$ & $1.82(0.88-3.77)$ \\
& & & $3.77)$ & \\
\hline
\end{tabular}

$\mathrm{n}=$ number of cases, $(\%)=$ percentage of cases, $\mathrm{OR}(95 \% \mathrm{CI})=$ Odds ratio \& $95 \%$ confidence interval.Significance using Fisher's Exact test: $* \mathrm{p}=<0.05$ (significant), $* * \mathrm{p}=<0.001$ (extremely significant) 
Table (3): Comparison between all cases with high socioeconomic standard with breast cancer and healthy controls regarding their allele frequency and genotype distribution of T-786C eNOS3, FOKI VDR, GSTT1 and GSTM1 gene polymorphisms.

\begin{tabular}{|l|l|l|l|l|}
\hline & $\begin{array}{c}\text { cases } \\
(\mathrm{n}=3)\end{array}$ & $\begin{array}{l}\text { H. controls } \\
(\mathrm{n}=36)\end{array}$ & $\mathrm{P}$ & OR (95\% CI) \\
\hline T-786C n(\%) & & & & \\
\hline TT & $1(33.3)$ & $29(80.6)$ & 0.12 & $0.12(0.009-1.52)$ \\
\hline TC & $1(33.3)$ & $7(19.4)$ & 0.50 & $2.07(0.16-26.23)$ \\
\hline CC & $1(33.3)$ & $0(0.0)$ & 0.07 & $43.8(1.3-1377.5)$ \\
\hline T & $3(50.0)$ & $65(90.3)$ & $\mathbf{0 . 0 2} *$ & $0.1(0.1-0.63)$ \\
\hline C & $3(50.0)$ & $7(9.8)$ & $\mathbf{0 . 0 2} *$ & $9.28(1.56-55.0)$ \\
\hline FOKI n(\%) & & & & \\
\hline FF & $0(0.0)$ & $30(83.3)$ & $\mathbf{0 . 0 0 9} *$ & $0.03(0.001-0.6)$ \\
\hline Ff & $3(100.0)$ & $6(16.7)$ & $\mathbf{0 . 0 0 9 *}$ & $32.8(1.5-716.5)$ \\
\hline Ff & $0(0.0)$ & $0(0.0)$ & 0.0 & 0.0 \\
\hline F & $3(50.0)$ & $66(91.7)$ & $\mathbf{0 . 0 1 *}$ & $0.09(0.01-0.55)$ \\
\hline F & $3(50.0)$ & $6(8.3)$ & $\mathbf{0 . 0 1 *}$ & $11.0(1.8-66.93)$ \\
\hline GSTT1 n(\%) & & & & \\
\hline Null & $3(100.0)$ & $3(8.3)$ & $\mathbf{0 . 0 0 2 *}$ & $67.0(2.83-158.2)$ \\
\hline Present & $0(0.0)$ & $33(91.7)$ & $\mathbf{0 . 0 0 2 *}$ & $0.01(0.0006-0.35)$ \\
\hline GSTM1 n(\%) & & & & \\
\hline Null & $2(66.7)$ & $7(19.4)$ & 0.12 & $0.12(0.00-1.52)$ \\
\hline Present & $1(33.3)$ & $29(80.6)$ & 0.12 & $8.28(0.65-104.9)$ \\
\hline
\end{tabular}

$\mathrm{n}=$ number of cases, $(\%)=$ percentage of cases, OR $(95 \% \mathrm{CI})=$ Odds ratio \& 95\% confidence interval.Significance using Fisher's Exact test: * $\mathrm{p}=<0.05$ (significant), $* * \mathrm{p}=<0.001$ (extremely significant)

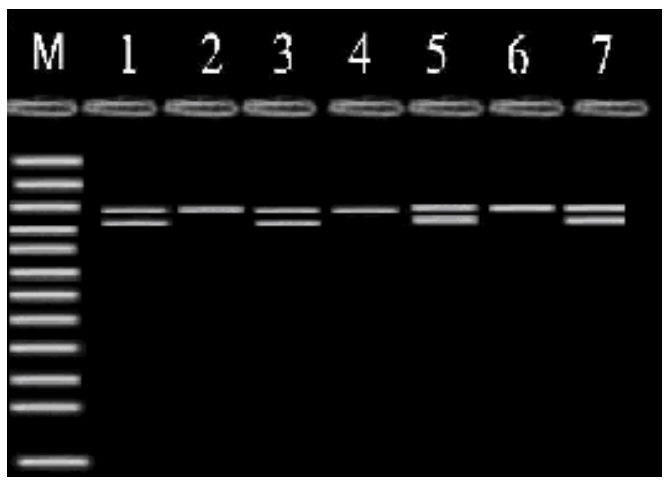

Fig (1): PCR amplification of GSTT1 polymorphism of GST gene. lane M: DNA marker size (50 bp).PCR product of GSTT1 polymorphism has band size 480 bp.PCR product of $\beta$-actin polymorphism has band size 493 bp (Internal control).Lane 2, 4 and 6 show deleted individuals showing absence of GSTT1 and positive amplification of B-actin (Internal control).Lane 1, 3, 5 and 7 show positive individuals showing presence of both GSTT1 and B-actin (Internal control). 


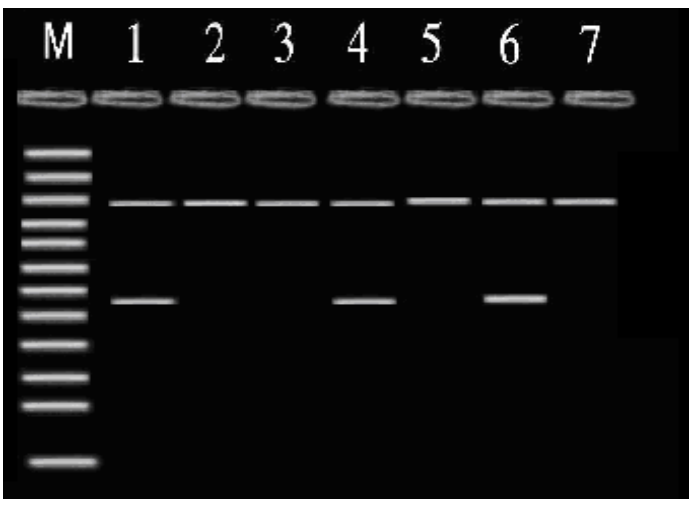

Fig (2): PCR amplification of GSTM1 polymorphism of GST gene. Lane M: DNA marker size (50 bp)

PCR product of GSTM1 polymorphism has band size 273 bp.PCR product of $ß$-actin polymorphism has band size493 bp (Internal control).Lane 2, 3, 5 and 7 show negative individuals showing absence of GSTM1 and positive amplification of $\beta$-actin (Internal control).Lane 1, 4 and 6 show positive individuals showing presence of both GSTM1 and B-actin (Internal control).

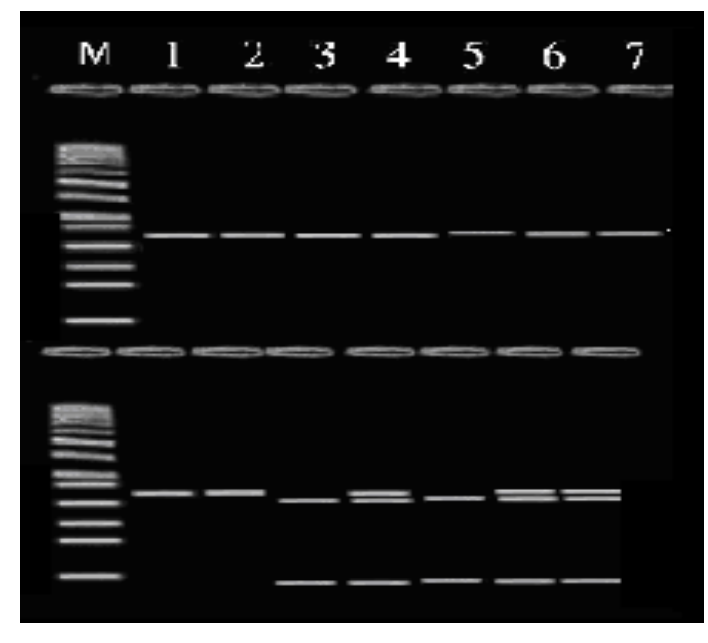

):(Above) PCR amplification of -786 3Fig ( polymorphism of eNOS3 gene. lane M: DNA marker size (50 bp),Lane 1-7: PCR product of $-786 \mathrm{~T} / \mathrm{C}$ polymorphism has band size $236 \mathrm{bp}$. (Below)Enzymatic digestion ; digestion of PCR product of $-786 \mathrm{~T} / \mathrm{C}$ polymorphism of eNOS3 gene using $\mathrm{NgOAIV}$ enzyme, which digests the 236- bp fragment into 203- and 33- bp frgments. lane 1 and lane 2 (wild type TT is found which appears at 236 bp).Lane 4, 6 and 7(heterozygous mutated genotype CT which has 236, 203, 33 bp fragments).Lane 3 and 5 (homozygous mutated genotype CC is found which has 203, 33 bp fragments)

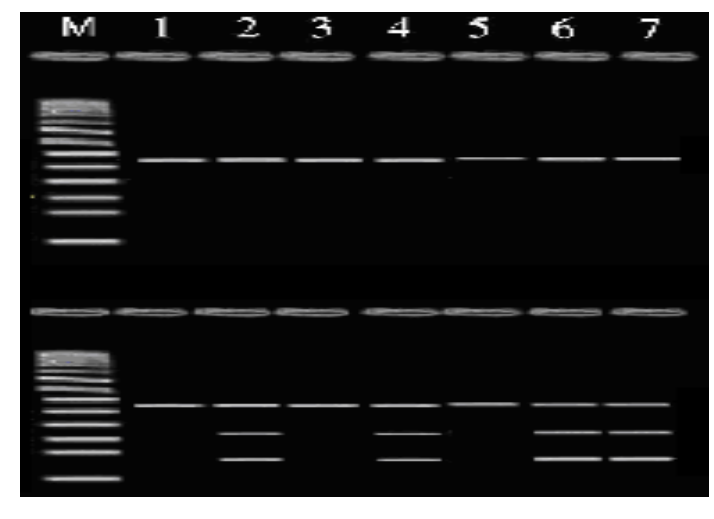

Fig (4):(Above) PCR amplification of FOKI polymorphism of VDR gene. Lane M: DNA marker size (50 bp).Lane 1-7: PCR product of FOKI polymorphism has band size 265 bp.(Below)Enzymatic digestion ; digestion of PCR product of FOKI polymorphism of VDR gene using Fok-I enzyme, which digests the 265bp fragment into 169- and 96- bp fragments.Lane 1, 3 and 5 (wild type FF is found which appears at 265 bp).Lane 2, 4, 6 and 7(heterozygous mutated genotype Ff which has 265, 169, 96 bp fragments). 


\section{Discussion}

Carcinogens in the body are detoxified by specific enzymes that aid in interception and removal from the cell or in modification involving addition of chemical residues to the reactive sites that cause

Analyzing studied Egyptian cases for combined genotypes, a certain pattern could be found to play a role in breast cancer susceptibility and/or severity. This included GSTT1(null) with GSTM1(present), that were shown to be significantly higher among all cases. On the other hand, GSTT1 (present) with GSTM1 (present) were found significantly low among cases pointing to possible protective effect of these genotypes.

This result was in agreement to what was previously reported in Caucasian population that breast cancer was significantly associated with GSTT1(null) and GSTM1(present)genotype; $(\mathrm{OR}=2.03$; 95\% CI=2.09-3.83; p=0.02) (Kostrykina et al.,2009) . Polymorphisms of combined genotypes were found to have an association with $\mathrm{BC}$ among Turkey and Caucasian population (Curran et al., 2000, Unlï et al., 2008). On the other hand, authors reported that there are an association of combined genotypes (GSTT1 null and GSTM1 null genotype) with BC (Woldegiorgis et al.,2002) contrasting what was reported before in the population of increased frequency of the GSTT1 null genotype with BC) (Dialyna et al.,2001\& Zheng et al.,2002).
DNA damage, allowing safe storage, prior to removal. Among these enzymes are the glutathioneS-transferase superfamilies of enzymes (Chiyomaru et al., 2011).

A similar low frequency of the GSTT1 null genotype among healthy controls can be found in the studies by Sergentanis $\&$ Economopoulos,2010,Chang et al. 2008 and Van Emburgh et al.,2008, these reporting increased risk of breast cancer among women with the GSTT1null genotype. These results are in contrast with Spurdle et al., 2010; Kostrykina et al.,2009 and Morais et al.,2008 who showed that no evidence for altered risk of breast cancer for individuals with the GSTT1 deletion.

In the current study, total cases showed GSTM1 in Egyptian with breast cancer cases found that no significant difference in the frequencies of all genotypes in total cases compared to controls. This result was in agreement to what was previously reported in Australian that BC has no associated with GSTM1 null genotype Kostrykina et al.,2009; Kadouri et al.,2008 and Morais et al.,2008). However, in another study among patients with $\mathrm{BC}$, null genotype was found increased in the patients compared to the normal controls $(\boldsymbol{Y u}$ et al., 2009; Qiu et al., 2010 and Roodi et al., 2004).

Nitric oxide (NO) mediates vascular smooth muscle relaxation, apoptosis, and 
various cytostatic and cytotoxic effects, and may increase growth rate, vascular density, and invasiveness of cancer. The role of $\mathrm{NO}$ as a mediator of malignant growth has been investigated demonstrating that $\mathrm{NO}$ has multiple independent effects on various levels of carcinogenesis (Loibl et al., 2005).

In the current study, total cases showed a significant higher frequency of eNOS3- $\alpha^{-786}$ CC genotype. Thus, eNOS3$\alpha^{-786} \mathrm{C}$ allele and $\mathrm{CC}$ genotype may be considered a risk marker for breast cancer among Egyptian families. On the other hand, significant lower frequency was observed with heterozygous genotype TT that was considered a low risk or protective genotype. The same was previously reported by Zintzaras $\boldsymbol{e t}$ al. (2010), Choi et al.,2009 and Lee et al. (2007), who supported that polymorphisms produced nonsignificant associations without significant heterogeneity. A positive association was detected for the promoter T786C polymorphism $(\mathrm{OR}=1.51$ (1.07-2.12)) in different populations.

Also, these results are in contrast with Choi et al. (2009), Lu et al. (2006) and Ghilardi et al. (2003) who found that women carriers of the eNOS $-786 \mathrm{C}$ allele had significantly risks increased $(\mathrm{OR}=$ $3.2,95 \%$ CI $=0.95-10.50)$ in different populations.

Vitamin D receptor (VDR) is a member of the steroid hormone family of nuclear receptors that are responsible for the transcriptional regulation of a number of hormone-responsive genes. VDR is expressed in normal mammary tissue, and more than $80 \%$ of breast tumor specimens are VDR positive. The natural ligand for VDR, 1,25-dihydroxyvitamin $\mathrm{D}_{3}\left(1,25-\mathrm{D}_{3}\right)$, as well as a number of novel synthetic vitamin D analogues inhibit proliferation and induce apoptosis in breast cancer cells in vitro (Grant et al. , 2011).

In the current study, it is noted that breast cancer cases had no significant difference in the frequencies of all genotypes and alleles in total cases compared to controls where $(\mathrm{P}>0.05)$ .But total cases with moderate socioeconomic standard with breast cancer showed a significant lower frequency of heterozygous genotype VDR FOKI (F/f) compared to controls $(\mathrm{OR}=0.31)$.Thus, VDR FOKI (F/f) genotype may be considered a protective genotype for breast cancer susceptibility.Also, comparison between cases present with high socioeconomic standard with breast cancer and controls breast cancer cases illustrated a significant lower frequency among homozygous cases with $\mathrm{F} / \mathrm{F}$ genotype $(\mathrm{OR}=0.02)$ that may be considered protective risk genotype accompanied by a significant lower frequency of $\mathrm{Ff}$ heterozygosity genotype $(\mathrm{P}=0.009)$ that may be considered low risk or protective genotype.

These results agreement with Abbas et al.(2008), Chen et al. (2005) and Guy et al. (2004), Ingles et al.,(2000) who 
fond VDR polymorphisms on postmenopausal breast cancer risk and possible differential effects of receptor status of the tumor in Germany population.

These results are in contrast with Köstner et al.,(2009), Tang et al. (2009) and Sinotte et al. (2008) who summarized that data indicating an association of VDR polymorphisms and cancer risk are strongest for breast cancer ( Fok1) in different populations.

\section{References}

1. Abbas S, Nieters A, Linseisen $\mathbf{J}$, Slanger T, Kropp S, Mutschelknauss EJ, Flesch-Janys D, Chang-Claude J(2008):Vitamin D receptor gene polymorphisms and haplotypes and postmenopausal breast cancer risk. Breast Cancer Res; 10(2):R31.

2. Bid HK, Mishra DK, Mittal $\mathbf{R D}$ (2005):Vitamin-D receptor (VDR) gene (Fok-I, Taq-I and Apa-I) polymorphisms in healthy individuals from north Indian population. Asian Pac J Cancer Prev; 6(2):147-52.

3. Chang YL, Li J, Yao SQ, Hu WN, Jiang SF, Guo Z, Yang L, Li DD, Li YM, Liu Y(2008): [A case-control study on serum organochlorines residues, genetic polymorphisms of glutathione Stransferase $\mathrm{T} 1$ and the risks of breast cancer]. Zhonghua Liu Xing Bing Xue Za Zhi; 29(8):763-6.

4. Chen WY, Bertone-Johnson ER, Hunter DJ, Willett WC, Hankinson SE(2005):Associations between polymorphisms in the vitamin $\mathrm{D}$ receptor and breast cancer risk. Cancer Epidemiol Biomarkers Prev;14(10):2335-9.

5. Chenevix-Trench,G., Young,J., Coggan,M. and Board,P (1995):Glutathione S-transferase M1 and T1 polymorphisms: susceptibility to colon cancer and age at onset. Carcinogenesis;(16), 1655-1657.

6. Cheng TJ, Christiani DC, Xu X, Wain JC, Wiencke JK, Kelsey KT(1995):Glutathione S-transferase mu genotype, diet, and smoking as determinants of sister chromatid exchange frequency in lymphocytes. Cancer Epidemiol Biomarkers Prev;4(5):535-42.

7. Chiyomaru K, Nagano T, Nishigori C(2011):Polymorphisms of glutathione stransferase in skin cancers in a Japanese population.Kobe J Med Sci;9;57(1):E116.

8. Choi JY, Barlow WE, Albain KS, Hong CC, Blanco JG, Livingston RB, Davis W, Rae JM, Yeh IT, Hutchins LF, Ravdin PM, Martino S, Lyss AP, Osborne CK, Abeloff MD, Hayes DF, Ambrosone CB(2009): Nitric oxide synthase variants and disease-free survival among treated and untreated breast cancer patients in a Southwest Oncology Group clinical trial. Clin Cancer Res;15;15(16):5258-66.

9. Comstock KE, Sanderson BJS, Claflin G, Henner WD (1990): GSTI gene deletion determined by polymerase chain reaction. Nucleic Acids; Res., 18:3670.

10. Curran JE, Weinstein SR, Griffiths LR (2009): Polymorphisms of glutathione Stransferase genes (GSTM1, GSTP1 and GSTT1) and breast cancer susceptibility. Cancer Lett.; 29;153(1-2):113-20.

11. Curran JE, Weinstein SR, Griffiths LR(2000): Polymorphisms of glutathione S-transferase genes (GSTM1, GSTP1 and GSTT1) and breast cancer susceptibility. Cancer Lett; 153:113-120.

12. Dialyna IA, Arvanitis DA, Spandidos DA (2001): Genetic polymorphisms and transcriptional pattern analysis of CYP1A1, AhR, GSTM1, GSTP1 and GSTT1 genes in breast cancer. Int J Mol Med;8(1):79-87.

13. Ghilardi G, Biondi ML, Cecchini $F$, DeMonti M, Guagnellini $E$, Scorza $R$ (2003):: Vascular invasion in human breast cancer is correlated to T-->786C polymorphism of NOS3 gene. Nitric Oxide; 9(2):118-22.

14. Grant WB, Juzeniene A, Lagunova $Z$, Porojnicu AC, Moan JE(2011):Vitamin D levels in Norway may be inadequate to reduce risk of breast cancer. Int $\mathrm{J}$ Cancer; 1;128(9):2249-50.

15. Gross C, Eccleshall TR, Malloy $\mathbf{P}$, Villa ML, Marcus R, Feldman D (1996): The presence of a polymorphism at the translation initiation site of the vitamin D receptor gene is associated with low bone mineral density in postmenopausal Mexican-American women. J Bone Miner Res; 11:1850-5.

16. Guy M, Lowe LC, Bretherton-Watt D, Mansi JL, Peckitt C, Bliss J, Wilson RG, Thomas V, Colston KW(2004):Vitamin D 
receptor gene polymorphisms and breast cancer risk.Clin Cancer Res; 15; 10(16):5472-81.

17. Hayes J.D. and Pulford D.J (1995): The glutathione S-transferase supergene family: regulation of GST* and the contribution of the enzyme to cancer chemoprotection and drug resistance. Crit. Rev. Biochem. Mol. Biol .,30, 445-600.

18. Kadouri L, Kote-Jarai Z, Hubert A, Baras M, Abeliovich D, Hamburger T, Peretz T, Eeles RA(2008): Glutathione-Stransferase M1, T1 and P1 polymorphisms, and breast cancer risk, in BRCA1/2 mutation carriers. $\mathrm{Br} \mathrm{J}$ Cancer; 17;98(12):2006-10.

19. King M-C, Roswell S, Love SM (1993): Inherited breast and ovarian cancer: What are the risks? What are the choices? JAMA; 269:1975-1980.

20. Köstner K, Denzer N, Müller CS, Klein R, Tilgen W, Reichrath J(2009): The relevance of vitamin $\mathrm{D}$ receptor (VDR) gene polymorphisms for cancer: a review of the literature. Anticancer Res; 29(9):3511-36.

21. Kostrykina NA, Pechkovskii EV, Mishukova OV, Khripko UI, Zarubina NA, Selezneva IA, Sinkina TV, Terekhova SA, Lazarev AF, Petrova VD, Filipenko ML (2009):.Studying the association of polymorphic variants of GSTM1 and GSTT1 genes with breast cancer in female residents of Altai Krai. Bull Exp Biol Med; 148(1):8993.

22. Kostrykina NA, Pechkovskii EV, Mishukova OV, Khripko UI, Zarubina NA, Selezneva IA, Sinkina TV, Terekhova SA, Lazarev AF, Petrova VD, Filipenko ML (2009): Studying the association of polymorphic variants of GSTM1 and GSTT1 genes with breast cancer in female residents of Altai Krai. Bull Exp Biol Med; 148(1):8993.

23. Lee KM, Choi JY, Lee JE, Noh DY, Ahn SH, Han W, Yoo KY, Hayes RB, Kang D(2007): Genetic polymorphisms of NOS3 are associated with the risk of invasive breast cancer with lymph node involvement. Breast Cancer Res Treat;106(3):433-8.

24. Lehman EM, Soliman AS, Ismail K, Hablas A, Seifeldin IA, Ramadan M, ElHamzawy H, Shoushtari CS, Wilson ML (2008): Patterns of hepatocellular carcinoma incidence in Egypt from a population-based cancer registry.Hepatol Res; 38(5):465-73.

25. Loibl S, Buck A, Strank C, von Minckwitz G, Roller M,Sinn HP, Schini-Kerth V, Solbach C, Strebhardt K, Kaufmann M(1995): The role of early expression of inducible nitric oxide synthase in human breast cancer. Eur J Cancer; 41(2):265-271.

26. Lu J, Wei Q, Bondy ML, Yu TK, Li D, Brewster A, Shete S, Sahin A, MericBernstam F, Wang LE (2006): Promoter polymorphism $(-786 t>C)$ in the endothelial nitric oxide synthase gene is associated with risk of sporadic breast cancer in non-Hispanic white women age younger than 55 years. Cancer; 1;107(9):2245-53.

27. Morais LM, Cardoso Filho C, Lourenço GJ, Shinzato JY, Zeferino LC, Lima CS, Gurgel MS(2008): Polymorphisms GSTM1 and GSTT1 and sporadic breast cancer mammographic features]. Rev Assoc Med Bras;54(1):61-6.

28. Nakayama $\mathbf{M}$, Yasue $\mathbf{H}$, Yoshimura $\mathbf{M}$ (1999): T(-786)-C mutation in the 5-primeflanking region of the endothelial nitric xide synthase gene is associated with coronary spasm.Circulation;99:2864-2870.

29. Qiu LX, Yuan H, Yu KD, Mao C, Chen B, Zhan P, Xue K, Zhang J, Hu XC(2010) :Glutathione S-transferase M1 polymorphism and breast cancer susceptibility: a metaanalysis involving 46,281 subjects.Breast Cancer Res Treat; 121(3):703-8.

30. Roodi N, Dupont WD, Moore JH, Parl FF(2004): Association of homozygous wildtype glutathione S-transferase M1 genotype with increased breast cancer risk.Cancer Res; 15;64(4):1233-6.

31. Seidegård J., Pero R.W., Miller D.J. and Beattie E.J. (1986): A glutathione transferase in human leukocytes as a marker for the susceptibility to lung cancer. Carcinogenesis; (7): 751-753.

32. Sergentanis TN, Economopoulos KP (2010): GSTT1 and GSTP1 polymorphisms and breast cancer risk: a meta-analysis. Breast Cancer Res Treat; 121(1):195-202.

33. Sinotte M, Rousseau F, Ayotte P, Dewailly E, Diorio $C$, Giguère $Y$, Bérubé S, Brisson J(2008):Vitamin D receptor polymorphisms (FokI, BsmI) and breast cancer risk: association replication in two case-control studies within French Canadian population. Endocr Relat Cancer; 15(4):975-83.

34. Stuehr DJ (1999): Mammalian nitric oxide synthases. Biochim Biophys; 1411(2-3):217-30.

35. Tang C, Chen N, Wu M, Yuan H, Du Y(2009):Fok1 polymorphism of vitamin $\mathrm{D}$ receptor gene contributes to breast cancer susceptibility: a metaanalysis.Breast Cancer Res Treat;117(2):391-9. 
36. Unlï A, Ates NA, Tamer L, Ates C(2008): Relation of glutathione $S$ transferase T1, MI and PI genotypes and breast cancer risk. Cell Biochem Funct; 2008 Sep-Oct;26(5):643-7.

37. Van Emburgh BO, Hu JJ, Levine EA, Mosley LJ, Perrier ND, Freimanis RI, Allen GO, Rubin P, Sherrill GB, Shaw CS, Carey LA, Sawyer LR, Miller MS(2008): Polymorphisms in CYP1B1, GSTM1, GSTT1 and GSTP1, and susceptibility to breast cancer. Oncol Rep; 19(5):1311-21.

38. Wiencke JK, Pemble S, Ketterer B, Kelsey KT(1995):Gene deletion of glutathione S-transferase theta: correlation with induced genetic damage and potential role in endogenous mutagenesis. Cancer Epidemiol Biomarkers Prev; 4(3):253-9.

39. Woldegiorgis S, Ahmed RC,Zhen Y, Erdmann CA,Russell LM,Goth-
Goldstein R (20002): Genetic Polymorphism in Three Glutathione Stransferase Genes and Breast Cancer Risk .Environmental Energy Technologies Division;115(3):537-43.

40. Yu KD, Di GH, Fan L, Wu J, Hu Z, Shen ZZ, Huang W, Shao ZM(2009):A functional polymorphism in the promoter region of GSTM1 implies a complex role for GSTM1 in breast cancer. FASEB $\mathrm{J} ; 23(7): 2274-87$.

41. Zheng L, Li S, Boyer TG, Lee WH (2000): Lessons learned from BRCA1 and BRCA2. Oncogene; 19:6159-6175.

42. Zintzaras E, Grammatikou M, Kitsios GD, Doxani C, Zdoukopoulos N, Papandreou C, Patrikidou A(2010):Polymorphisms of the endothelial nitric oxide synthase gene in breast cancer: a genetic association study and metaanalysis. J Hum Genet; 55(11):743-8. 


\title{
التثخيص الجيني الجزيئي لجينات الإنزيم الناقل للجلوتاثيون و الإنزيم المكون لأكسيد النيتريك ومستقبلات فيتامين د في حالات سرطان الثذي لانيزي
}

\author{
رزق الباز1، عزة إسماعيل2، ماهر عامر 2 ، مى الثحات3، أميرة قزامل2 ، أحمد ستين1 .

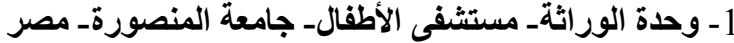

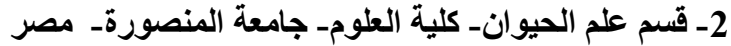 \\ 3- مدرس الأشعة العلاجية والأورامـ كلية طب - جامعة المعة المنصورة- مصر
}

استهدفت الدر اسة موضو عا حيو يا و هاما فى الججال الفسيولوجي الجزيئي الطبي وكان من الجينات التي تستحق

الدراسـة وتعتبر مههة فى مرض سرطان الثدى وهى جينات الإنزيم الناقل للجلوتاثيون و الإنزيم المكون لأكسيد النيتريك ومستقبلات فيتامين د.

أوضحت هذه الدر اسة أن هناك أثكال معينة في التركيب الجينى الوراثي لجينات الإنزيم الناقل للجلوتاثيون و الإنزيم

المكون لأكسيد النيتريك موجودة بنسبه إحصائيةعالية فى الحالات المرضية عنها في الأصحاء.

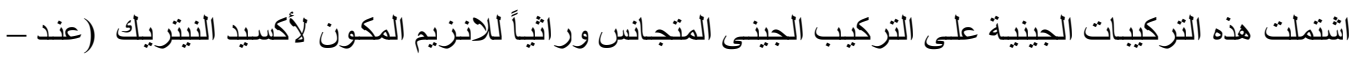

786) سيتوزين/سيتوزين و الإنزيم الناقل للجلوتاثيون ثيتا(null) و التي يمكن أن تعتبر خطيرة وتعرض الأشخاص حامليها لتطور المرض.

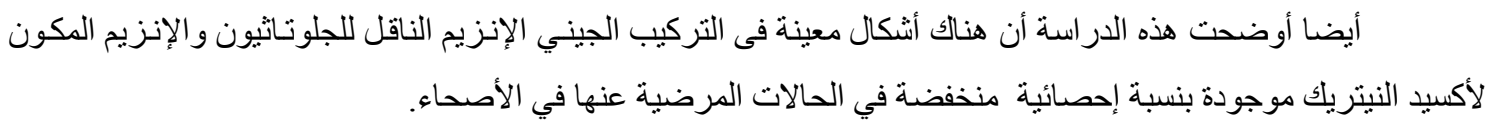
اشتملت هذه التركيبات الجينية على التركيب الجينى متجانس ور اثياً للانزيم المكون لأكسيد النيتريك (عند الاهد -

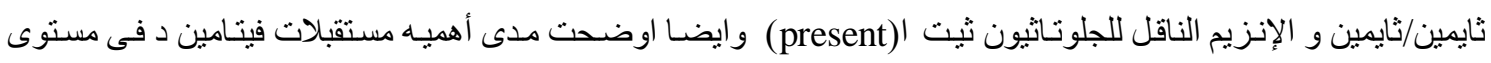

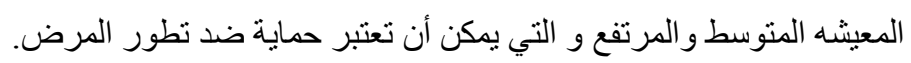

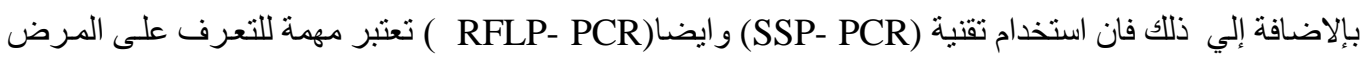
وبيان شدة خطورته. 